\title{
The Essentials Of Cross Training: The Benefits Of Delegation And The Role Of Education
}

Joseph B. Mosca, (E-mail: mosca@monmouth.edu), Monmouth University John Buzza, (E-mail: jbuzza@monmouth.edu), Monmouth University

Stuart Abraham, (E-mail: sabraham@monmouth.edu), Monmouth University

\begin{abstract}
Bob Hunter is the operations manager for a medium sized manufacturing plant that produces after market automobile parts. The line of products includes: alternators, starters, rebuilt air-conditioner compressors, disk-brake pads and replacement kits, and electric motors for power windows and seats. Bob has been having difficulty meeting deadlines due to increased orders and he met with his boss, the director of operations saying: "Mr. Conner, I am pushing my crew to the limits, I seem to be running around from department to department since I lost my assistant, and meeting production deadlines is becoming difficult. Can I hire at least two more employees to increase production? "Sorry Bob, but the budget will not allow it and you will have to increase efficiency. Our raw materials costs have increased and the competition is not raising their costs." "Do you have any suggestions that can help me?" asked Bob. "First I have a couple of questions for you; are your employees cross trained and how much work do you delegate? If not, you should give it some serious consideration. As you know Bob, changes in management are essential in order for us to remain competitive. When you hired your employees, did you give any thought to how flexible they were?" No organization can survive today without employees that can meet the challenge of rapid change. This paper is not to discuss change, but how cross training employees can increase efficiency, and how education is helping to prepare future employees.
\end{abstract}

\section{INTRODUCTION}

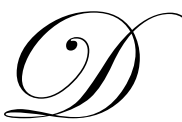

uring these times business is under many pressures and change is inevitable, with shorter deadlines, fewer employees, flattened organizational structures and the ability to produce efficiently. Thus far managers are taking on more responsibilities, but taking on more can be counter productive. When daily pressures begin to take hold there is a solution to the problem and that is delegation. If delegation is approached properly, it can be effective for the immediate results allow managers to mobilize employees to achieve increased results that the manager could not do alone. Shared responsibilities help the manager to focus on fewer tasks, it provides more time for motivating employees, lending support when needed, and assisting those employees who need help to meet organizational goals.

The organizational structure becomes informal, opening lines of communication, engages employees in what objectives need to be met, allows for shared decision making, increased efficiency and productivity. Therefore the organization becomes more responsive to change to remain competitive (Gasda, 2002).

In today's global village and the continuing intensifying competition, it is clearly a priority for managers at all levels to maximize the efficiency of their workforce. At the same time, employees are experiencing dislocations resulting from downsizing and outsourcing, resulting in changing the social contract between employee and employer. The social contract of loyalty in exchange for job security has been destroyed. The new social contract between the employee and employer is based on mutual gain. The employee's perspective is "what will I learn as a result of me 
working here to improve my employability. While the employer's perspective is, "how can I achieve the maximum productivity from my employees?"

The suggestion here to successfully approach the social contract is to consider an interdisciplinary approach to training, or cross training employees, whereby both employer and employee benefit. This paper explores the dimensions of the benefits to the employee and employer. Employees will be surveyed to assess their point of view on cross training.

\section{HUMAN RESOURCE DEVELOPMENT REDUCES COSTS}

When organizations invest in employee development production output can remain the same with reduced staff. Investing in employee development is a benefit and confirmed by Follette (2001), operational efficiencies remain high, through employee development when management considers the following: Retain employees eligible for retirement who possess organizational knowledge rather than letting them go. Hiring new operational employees can impact productivity and costs, this should be minimized to its lowest level. Follette (2001), suggests the following strategies: Record and prioritize operational tasks required to meet organizational goals. Review all work processes and implement efficiency. Assign work to all employees efficiently. Conduct job-analysis to define job skills to establish standards to evaluate performance. Provide employees with a comprehensive breakdown of work to be performed. Establish priorities efficiently. Open lines of communication in order for all employees so they comprehend expectations. Provide continual training and development.

In the UK employee development has become paramount and keeping employees skills base levels has become the strategy to remain competitive in an increasingly competitive global market. To accomplish this it requires an adaptable workforce capable of carrying out flexible tasks and learning new skills, in order to deal with change and efficiencies (Essery, 2001).

\section{CROSS TRAINING INCREASES EMPLOYEE EFFICIENCY}

Developing employee skills is a component of cross training. Employee development is based on the type of business and organizational goals, therefore, customized and tailored to the organization. Employees who experience cross training gain a full view of the organization and are exposed to the stated goals the company wants to achieve. It is evident that either the organization or the employee can analyze what an individual needs when development practices are in use. Prior to cross training employees, the goal is to identify their strengths and weaknesses. Then the manager can determine what capabilities the employee has to carry out organizational plans.

Both external and internal forces cause organizations to restructure. Employees may encounter job redesign, require more training, be able to operate new equipment, and they may have to establish new interaction patterns of communication. Cross training employees before changes in structure occur can maintain efficiencies and reduce production loss. An example of cross training would be: A large four color printing press that requires a team consisting of a master press operator, operator assistant for each color unit, two attendants, a press loader and unloader, all of which tend the printing press while it is in operation. Efficiency can be maintained if all four of the operator assistants and the two attendants are cross-trained in the operation and components of the printing press. All should be familiar with paper-weight adjustments, how printing plates are attached to the press, the balance of chemicals and ink distribution, and how to evaluate quality of the work being produced. When large printing equipment is operational they are capable of producing thousands of sheets per hour and quality is of the utmost importance. There are many variables when printing equipment is in operation such as: humidity, paper grain direction, ink coverage, press speed, chemical balance, and waste reduction. If all attendants and all assistants are familiar with the variables and how to cope with them, malfunctions can be detected early and corrected, and understanding the component parts of the printing press can serve as a preventive measure to insure quality (Aichlmayr, 2000, Fenton, 2001). When a large four color printing press comes to a halt for adjustments during operation it is costly and quality is reduced because many printed sheets are wasted before the press is brought up to running speed. Cross training can reduce down time, because all team members skills have been developed and response time to malfunctions can be greatly reduced (Nighswonger, 2001). 
Cross training is similar to mentoring for it requires other employees who have skills to spend time with those to be cross-trained. On the surface this concept of cross training may seem time consuming and costly, but will save time and money over the long term. When the following long-term advantages are considered it will become evident that cross training is efficient:

As with the operation of the four-color printing press, the whole team becomes aware of the workflow and can anticipate problems or requirements in other areas of the press's operation. Cross training can be used as a motivational tool because it removes the feeling for employees of being in a dead end job without improving their job skills. Productivity can be maintained during employee absence periods, and overtime can be reduced during this time. Employees can develop latent skills they did not know they had. Tedious tasks can be spread out to more employees reducing stress (Weiss, 2000).

\section{WHAT ARE EDUCTORS DOING TO PREPARE FUTURE WORKERS?}

According to Bisoux (2002), the pedagogical pendulum is swinging again, toward teaching across disciplines. Currently, integrated education is catching on across the US and corporate recruiters are noticing. Educators are well aware of the need for new $21^{\text {st }}$ century employee who will need flexible job skills, problem solving skills, and capable of becoming part of a team. Organizations are seeking prospective employees who can look across many areas and see the big picture.

Stumpf and Tymon (2002), support integrated education as well, for they believe this approach is taking hold. Integrated learning is related to the real world of work, for business problems are complex and solutions to these problems go far beyond functional boundaries. Traditionally, the rigorous academic approach relied on theory, models, abstract thought, and did not demonstrate practical, immediate relevance. Contemporary employers want to recruit prospective employees who have the capability of reflecting on the realities of the business world.

\section{THE STUDY}

The purpose of this paper was to determine whether or not companies are engaged in the cross training of their employees, and if organizations incorporate an employee development program to assist their workers with career advancement.

\section{Research Goals}

The goals of the study were (a) to identify useful perspectives of cross training of employees (b) to clarify if employees surveyed were members of work teams (c) if employees felt that cross training was important for their career development and (d) if employees would seek out organizations who offer cross training and employee development programs.

\section{Methodology And Analysis}

A survey was distributed to 106 undergraduate and 82 graduate students who were currently employed. There were 105 males 24 of which were from a minority group and 83 females of which 18 were from a minority group. Originally the number of surveys distributed was 200 of which 188 were returned.

\section{INSTRAMENT}

The survey asked the following:

1. Does your organization have an employee retention program?

2. Are you a member of a work team?

3. Does your organization cross train employees?

4. Have you been cross trained? 
5. Have you ever taken an interdisciplinary course?

6. Would cross training help you in your career?

7. Are you familiar with cross raining methods?

8. Does your organization have an employee development program?

\section{RESULTS}

The surveys revealed that $35 \%$ of the organizations had a retention program, $46 \%$ of the employees were part of a work team, $55 \%$ of the respondents were employed in organizations that cross trained, while $55 \%$ were cross trained, only $25 \%$ had taken an interdisciplinary course, $93 \%$ of the respondents believed that cross training would help their careers, $84 \%$ were familiar with cross training, and $93 \%$ worked in organizations that had employee development programs.

\section{DISCUSSION}

The ability of today's workforce to multi-task becomes a key component in their overall success ratio. Take the athlete that must compete for either a scholarship or a position on an established team. If this person has the ability to play more than one position, and the knowledge to understand most or all of the others, how much more valuable is he to the team? "I need my players to be able to play more than one position. I teach that. If someone goes down, why use an inferior sub. I play my best nine players at all times, but if one isn't available, I want to use the $10^{\text {th }}$ best. I don't want to use the $15^{\text {th }}$ best because he's the only one that knows that position. Sure, it takes some juggling, but I want \# 10 on the field, not \#15". (Robert Amendola, 2005).

Business certainly is no different. We all aspire to reach the managerial level. Does reaching that level become dangerous and quite precarious if our knowledge of the entire operation is strictly single dimensional? If individually or organizationally we only value our specific job, how good are we then to our employer?

Cross training, as it relates to a persons business savvy, has its roots in education. We see it in every school curriculum from grade school to graduate school. We study a variety of courses, always trying to understand the whole equation rather than just its parts. Finance majors must take courses in music, history, English, science and the like. The idea is to graduate a well rounded individual, someone who brings more than just a financial mind to the table. Role players in business are important, but awareness and knowledge of your entire surroundings is much more critical. Relating back to our reference in sports, a basketball team will be more successful with five accomplished role players that also can play other positions than a team made up of two superstars and three underachievers knowing only their jobs. The superstar laced team might win more games in the short term on sheer talent, but not over a long hall. American business is built for longevity. What happens to the team if one or two of the superstars goes down? Is there anyone that can take their place and keep the productivity level constant? Compare that to the team of seasoned role players. Any one of the other four can fill the gap and keep productivity at a sustained level. In an interview with syndicated sports writer Jerry Izenberg of the Star Ledger, he discussed the need for knowledge of all sports. "I'm a SPORTS writer. If I am not acutely aware of the intricacies in EVERY sport I cover, what happens when the seasons change? Can I be excellent in reporting baseball, fair in reporting football and lousy in basketball? I would be out of a job in 10 minutes!” (Jerry Izenberg, The Star Ledger, 2005)

Cross training also has a trickle down effect on Corporate Social Responsibility. It is obvious that the employee benefits from his ability to multi task, but what about the company? Everybody loves a winner. The ability to insure yourself against decreased productivity through productive cross training of employees increases your ability to "win" in the minds of consumers. Corporate image, as a component of success, just might be the single most important factor in corporate longevity. Not only does everyone love a winner, but everyone wants to play for a winner. The ability to attract a better employee also has its roots in cross training. As cross training permeates throughout an organization, employees realize they are not the only person that can do their job. Does the "fear factor" of being replaced make you perform better? Can a case be made for employees becoming more diligent and productive in their jobs if they feel they are ultimately replaceable? Security as it relates to proficiency is a good thing. However, relating security to a demand curve can certainly work in the opposite direction. 
"Selecting an employee is the last step in employing qualified applicants after a sufficient pool of applicants has been drawn and potential employees have been interviewed". (Lindner \& Zoller, 1996; Zoller 1996) The ability of employees to cut down on mistakes, become more aware of their responsibilities and work with a sense of entrepreneurship is a direct result of proper training. A committed employee will work his task with a mentality of "doing it right the first time". This theory has its foundation in both the social contract that is established between the employee/employer relationship and the knowledge the employee has of his responsibilities. In his book "Doing It Right The First Time", Nierenberg points out how we might turn our mistakes into benefits. He tells us that awareness is the key, not just of our job but of the entire operation. The ability to relate what we do and how it affects the organization as a whole remains a significant factor in our productivity.( Doing It Right The First Time: A Short Guide To Learning From Your Most Memorable Errors, Mistakes and Blunders, 1996) Cross training on the job and in the classroom gives us that insight.

It seems so elementary to business, but working on different levels identifies the importance of having employees that are savvy and show awareness. What happens when employees call in sick, or take time off from work because of personal reasons? And what happens when employees have to travel away from the office or are just having the proverbial "bad day"? Do we just reduce our productivity during these times or do we have others that can "hold down the fort" because of their ability to assume additional responsibilities? WFS Financial Inc., one of the nation's largest independent auto-finance companies found that turnover had risen steadily for three consecutive years, reaching 32.75 percent by the end of 2003 and costing approximately \$5million annually. However through peer coaching of which cross training was a significant part, WFS was able to profoundly impact their turnover rate down to a manageable 5.13\%. (Workforce Magazine Online, February 2005).

\section{CONCLUSION}

Cross training should be considered at all levels of management because the benefits are two fold. Firstly the experiences employees gain benefit the employee and company as well because workers have a rounded view of the goals to attain. Secondly the organization has trained employees who understand objectives that are beyond their specific area and will fit better into work teams. Functional teams can effectively solve organizational problems when the teams are structured properly. Work teams allow employees to be self directed and leaders emerge. Yes this study needs to be expanded but our objective was to first determine if cross training was needed and considered. In addition, to answer the question: are employees interested in cross training.

\section{REFERENCES}

1. Aichlmayr, Mary, (2000). Solving The People Problem: Part II: Maximizing People Productivity, Transport \& Distribution, Number 10, pp. 89-98.

2. Amendola,Robert (2005). (Interview) Assistant Varsity Baseball Coach, Bullard High School, conducted 8/23/05.

3. Bisoux, Tricia, (2002). Connecting the Dots St. Louis, Biz-Ed, January/February, 2002, pp. 40-42.

4. $\quad$ Essery, Elaine, (2001). Flexible Benefits, Horton Kirby, Works Management, Volume 54, Issue 12, pp. 1517.

5. Fenton, Howard, (2001) Breaking Bottlenecks, Folio: The Magazine for Magazine Management, Volume 30, Number 7, p. 68.

6. Follette, Daniel, (2001). How Strategic Personnel Development Can Reduce Operation Costs, Tulsa, Oil \& Gas Journal, Volume 99, Issue 46, pp. 70-78.

7. Gazda, Sharon, (2002). The Art of Delegating, Alexandria, HR Magazine, Volume 47, Issue 1, pp. 75-78.

8. Izenberg, Jerry (2005. (Interview) Syndicated Columnist The Star Ledger, conducted 8/24/05.

9. Linder \& Zoller, (1996). Filling a Position In Small Business, Ohio State University Fact Sheet, Volume 1383 , pp. 97.

10. Nierenberg, Gerard I, (1996) Doing It Right The First Time: A Short Guide to Learning From Your Most Memorable Errors, Mistakes, and Blunders, Wiley Publications, September, 1996, 310 pages.

11. Nighswonger, Todd, (2001). Ready for Any Emergency. Occupational Hazards, Volume 63, Number 7, pp. 35-36. 
12. Stumpf, Stephen, Tymon, Walter, (2002). Why Integrated Education Over Functional, Biz-Ed, January/February, 2002, pp. 44-45.

13. Weiss, W., (2000) Training Methods and Programs, Supervision, Volume 61, Number 1, pp. 9-13.

\section{NOTES}

